\title{
Evaluation of epicardial fat thickness and carotid intima-media thickness in the patients with subclinical and overt hypothyroidism
}

\section{Subklinik ve aşikar hipotiroidili hastalarda epikardiyal yağ kalınlığı ve karotisintima-media kalınlığının değerlendirilmesi}

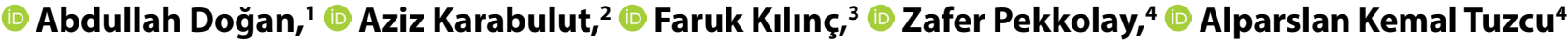 \\ 'Department of Internal Medicine, Bitlis State Hospital, Bitlis, Turkey \\ ${ }^{2}$ Department of Cardiology, Dicle University Faculty of Medicine, Diyarbakır, Turkey \\ ${ }^{3}$ Division of Endocrinology, Department of Internal Medicine, Firat University Faculty of Medicine, Elazığ, Turkey \\ ${ }^{4}$ Division of Endocrinology, Department of Internal Medicine, Dicle University Faculty of Medicine, Diyarbakır, Turkey
}

\begin{abstract}
Introduction: The studies conducted have shown that epicardial fat thickness (EFT) and Carotid intima-media thickness (CIMT) are closely associated with cardiovascular diseases and that this may be an indicator for the prediction of early atherosclerosis. Inthisstudy, we have attempted toidentify EFT and CIMT in patients with hypothyroid is mand toreveal the relationship between them and thyroid hormones.

Methods: 82 patients diagnosed with primary hypothyroidism and 37 patients from healthy control group were included in the study. The subclinic hypothyroidism group (SH) was made up of 50 patients; the overt hypothyroidism group $(\mathrm{OH})$ was composed of 32 patients. Cases' thyroid-stimulating hormone (TSH), FT3, FT4, thyroperoxidase antibodies (anti-tpo) and anti-tiroglobulinantibodies (anti-tg) were studied. Their EFT and CIMT values were measured. The statistical analysis was applied to EFT and CIMT.

Results: Compared with the CG, the thickness of epicardial fat tissue increased in $\mathrm{OH}$ and $\mathrm{SH}$ groups ( $<<0,001, \mathrm{p}<0,001$ respectively). In terms of EFT, there was no significant difference between $\mathrm{OH}$ and $\mathrm{SH}$ groups. Compared with the CG, the mean CIMT increased in $\mathrm{OH}$ and $\mathrm{SH}$ $(p<0,001, p<0.001$ respectively), but there was no significant difference between $\mathrm{OH}$ and $\mathrm{SH}$ in terms of CIMT. In addition, there was a positive correlation between EFT and CIMT $(p<0.001)$.

Discussion and Conclusion: The measurement of EFT and CIMT can be used as a marker for the diagnosis of early atherosclerosis both in $\mathrm{OH}$ and in SH patients. Because the thickness of EFT and CIMT increased in patients with $\mathrm{SH}$ who are debated as to whether they should be treated, it leads us to think that these patients should be treated in order to reduce the risk of cardiovascular diseases in these patients.
\end{abstract}

Keywords: Epicardial fat thickness; carotid intima-media thickness; hypothyroidism.

\section{Özet}

Amaç: Aşikar olsun subklinik olsun hipotiroidininkardiyovasküler sistem üzerine birçok etkisi vardır. Epikardiyal yağ kalınlığı (EFT) ve Karotisintima-media kalınlığının (CIMT) kardiyovasküler hastalıklarla yakın ilişkisi yapılmış çalışmalarla ortaya konulmuş ve erken ateroklerozun öngörüsünde bir belirteç olabilecekleri belirtilmiştir. Bu çalışmada hipotiroidili hastalarda EFT ve CIMT değerlerini saptamayı ve bunların tiroid hormonları ile ilişkisini ortaya koymayı amaçladık.

Gereç ve Yöntem: Bu çalışmaya 82 primerhipotiroidi tanılı hasta, 37 sağ|ıklı kontrol gubu (KG) olgusu dahil edildi. Subklinikhipotiroidi grubu (SH) 50; aşikarhipotiroidi grubu (AH) grubu 32 hastadan oluşuyordu. Olguların tiroid uyarıc hormon (TSH), serbset t3 (FT3),serbest t4 (FT4), anti tiroidperoksidaz (anti-TPO), anti tiroglobülin (antı-TG) değerleri çalışıldı. EFT ve CIMT değerleri ölçüldü. EFT ve CIMT için korelasyon analizleri uygulandı. SPSS 18.0 bilgisayar programı ile çalışmanın istatistiksel değerlendirmesi yapıldı. $\mathrm{P}<0.05$ istatistiksel olarak anlamlı kabul edildi.

Bulgular: Ortalama değerler EFT için $\mathrm{SH}, \mathrm{AH}$ ve $\mathrm{KG}$ 'da sırası ile $5.49 \pm 0.71$ $\mathrm{mm}, 5.05 \pm 0.98 \mathrm{~mm}, 3.62 \pm 0.75 \mathrm{~mm}$ CIMT için SH, AH ve KG'da sırası ile $0.59 \pm 0.12 \mathrm{~mm}, 0.58 \pm 0.12 \mathrm{~mm}, 0.43 \pm 0.8 \mathrm{~mm}$ bulundu. AH ve SH grupta KG'na göre EFT artmıştı (sırası ile $p<0,001, p<0,001$ ). AH ile SH grup arasında ise EFT yönüyle anlamlı farklılık yoktu. AH ve SH grupta KG'na göre CIMT artmıştı (sırası ile $p<0,001, p<0.001$ ). AH ile SH grup arasında ise CIMT yönüyle anlamlı farklılık yoktu. Ek olarak EFT ile CIMT arasında pozitif korelasyon vardı $(\mathrm{p}<0.001)$.

Sonuç: EFT ve CIMT ölçümü hem AH hem de SH hastalarda erken ateroskleroz için faydalı bir belirteç olarak kullanılabilir. Özellikle de tedavi edilip edilmemesi konusu tartışmalı olan SH hastalarda artmış EFT ve CIMT bulunması bu hastaların kardivasküler hastalık riskini azalmak için tedavi edilmesi gerektiğini göstermektedir.

Anahtar Sözcükler: Epikardiyal yağ kalınlığl; karotisintima-media kalınlığl; hipotiroidizm. 
$\mathrm{H}$ ypothyroidism is a syndrome characterized by tiredness, forgetfulness, indigestion, coarseness in voice, infertility, muscular pain and bradicardia (1). This clinical table is called primary hypothyroidism if it results from the inefficiency of thyroid gland, secondary hypothyroidism if it is caused by the inefficiency of TSH and tertiary hypothyroidism if it occurs as a result of the inefficiency of thyroid releasing hormone. The most common reason for primary hypothyroidism is hashimoto thyroiditis and is divided into overt and subclinical hypothyroidism based on the serum TSH level $(2,3)$. High TSH level is classified as overt hypothyroidism when free T3 (FT3) and/or free T4 (FT4) levels are low; high TSH and the absence of clinical indicators of overt hypothyroidism when FT3 and FT4 are normal is called subclinical hypothyroid. Subclinic hypothyroidism is a case clinicians frequently encounter in daily practice. The main question is whether these patients should be treated or followed without treatment. It is noted that EFT is an important risk factor for coronary arterial disease (CAD) and that it is a marker of visceral fat tissue around myocardium correlated with central obesity (4). What kind of relationship EFT and CIMT have with CAD is a topic heatedly debated today. In the studies conducted, it was found that there is a significant relationship between CIMT and coronary vascular disease (CVD), and it is thus stated that CIMT could be used in predicting the risk of CVD (5). Hypothyroidism, particularly the relationship of SH with EFT and CIMT, has become the subject of research in recent years, but there are a limited number of studies in this regard. In our study, we have tried to throw light on the relationship between subclinic hypothyroidism and CVD, which is not still clear, by measuring EFT and CIMT in patients with hypothyroidism.

\section{Materials and Method}

The patients diagnosed with hypothyroidism when they applied to the Medical Faculty of Dicle University were included in this study. We included 82 patients diagnosed with hypothyroidism and 37 healthy patients as control group in the study. The patients diagnosed with hypothyroidism were separated into two subgroups, $\mathrm{OH}$ and $\mathrm{SH}$, depending on their levels of TSH and FT4 levels. The patients with increased TSH $(>4,20 \mathrm{mlU} / \mathrm{mL})$, decreased FT4 $(<12 \mathrm{mlU} / \mathrm{mL})$ and positive (>35 mlU/mL) antı-tpo were designated as $\mathrm{OH}$ group, whereas the patients with increased TSH, normal FT4 and positive antitpo were designated as in the $\mathrm{SH}$ group. There were 8 male and 42 female patients in the SH group, 4 male and 28 female patients in the $\mathrm{OH}$ groups. Those with such conditions as a known heart disease, the metabolic syndrome, diabetes mellitus, obesity (BMI>30) and hypertension (TA>140/90) were not included in the study. The systolic blood pressures (SBP) and diastolic blood pressures (DBP) of the patients were measured with mercury sphygmomanometer while they were sitting in a silent environment and recorded. EFT of the patients was measured with transthoracic echocardiography and their CIMT was measured with a doppler ultrasound device. Therightandleftside CIMT wasmeasuredandmeanvalueswer- erecorded. The control group was made up of healthy volunteers with no known chronic disease. Written consent was obtained from all the volunteers. An application was filed to the medical research ethical board of Dicle University. After the approval was confirmed, the study was started (project no: 223, confirmation date: April 15, 2015).

\section{Hormone and biochemical measurements}

TSH, FT3, FT4 anti-tpo and anti-tg antibody titers, insulin levels, LDL-cholesterol (LDL-c), HDL- cholesterol (HDL-c), triglyceride (TG), total- cholesterol ( $T$ - chol) and VLDL-c values of the cases were studied. Their levels of TSH, FT4, FT3, anti-tg and anti-tpo were measured with the method of Electrochemiluminescence Immunoassay (ECLIA). The ranges of 0.270-4.20 $\mathrm{mlU} / \mathrm{mL}$ for TSH, 12-22 pmol/L for FT4 and 0-35 IU/mL for antitpo were accepted as normal values for euthyroidism.

\section{Epicardial fat thickness and carotid intima-media thickness measurement}

EFT in all cases was evaluated through an HP HD 211 (Philips Holland) Electrocardiographic device and 2,5 MHz electrocardiography probe. EFT was measured in "mm" by an experienced cardiologist who had no knowledge of the clinical and demographic traits of the patients through a 2-D echocardiography device from parasternal long axis and parasternal short axis images over the right ventricular free wall. CIMT was measured through an ultrasonography device (AlokaProsound SSD 5000 machine; Japan) using a probe of $7,5 \mathrm{mHz}$ linear probe, from the right and left main carotid artery in a longitudinal position $10 \mathrm{~mm}$ proximal to bifurcation. The mean values of the measurements of the both sides were recorded in " $\mathrm{mm}$ ".

\section{Statistical analysis}

The statistical evaluation of the study was conducted through SPSS 18.0 (statistical package for social sciences). The value of $\mathrm{P}<0.05$ was considered statistically significant. The results were given as mean \pm SD and percent (\%). In order to compare all the three groups, one-way Anova test was used. The independent t-test was employed for the comparison of two groups, and the student t-test was used for the comparisons between the groups and variables. The Pearson correlation variables were used for the correlation analysis between parameters. The regression analysis was carried out through such variables as EFT and CIMT dependent variables, age, BMI, SBP, DBP, TSH, FT4, FT3, LDL-c, HDL-c, TG, T-chol and VLDL-c.

\section{Results}

$50 \mathrm{SH}$ patients, $32 \mathrm{OH}$ patients and $37 \mathrm{CG}$ patients were included in the study. The average ages of the patients were measured to be $35,3 \pm 9,5$ and $37,4 \pm 9,6$ for $\mathrm{SH}$ and $\mathrm{OH}$ groups respectively. The comparison of the findings in all the three groups is given in brief in Table 1. Gender, age, BMI, FPG, SBP, DBP, LDL-C, HDL-c, T-chol and TG levels did not differ significantly among the three groups. Levels of serum TSH, FT4, FT3, anti- tpo, anti-tg and Homa-IR differed significantly among 
Table 1. Clinic laboratory and echocardiographic data for all study cases

\begin{tabular}{|c|c|c|c|c|}
\hline Parameters & SH & $\mathrm{OH}$ & CG & $\mathbf{P}$ \\
\hline Gender (M/F) & $8 / 42$ & $4 / 28$ & $6 / 31$ & NS \\
\hline Age (year) & $35.3 \pm 9.5$ & $37.4 \pm 9.6$ & $35.6 \pm 1.9$ & NS \\
\hline BMI $\left(\mathrm{kg} / \mathrm{m}^{2}\right)$ & $25.2 \pm 3.8$ & $26.2 \pm 3.9$ & $31.4 \pm 44.9$ & NS \\
\hline $\mathrm{SBP}(\mathrm{mm} / \mathrm{Hg})$ & $119.4 \pm 12.8$ & $124.8 \pm 13.1$ & $120.9 \pm 13.8$ & NS \\
\hline $\mathrm{DBP}(\mathrm{mm} / \mathrm{Hg})$ & $74.0 \pm 8.9$ & $78.20 \pm 9.5$ & $74.7 \pm 7.3$ & NS \\
\hline $\mathrm{TSH}(\mathrm{mlU} / \mathrm{mL})$ & $7.9 \pm 3.6$ & $18.8 \pm 16.2$ & $1.6 \pm 0.8$ & $<0.001$ \\
\hline FT3 (pmol/L) & $4.8 \pm 0.8$ & $4.3 \pm 1.3$ & $5.2 \pm 0.6$ & 0.001 \\
\hline FT4 (pmol/L) & $14.7 \pm 1.8$ & $9.7 \pm 2.4$ & $16.4 \pm 2.1$ & $<0.001$ \\
\hline Anti-TPO (IU/mL) & $207.3 \pm 227.1$ & $216.5 \pm 210.8$ & $16.4 \pm 18.5$ & $<0.001$ \\
\hline Anti-TG (IU/mL) & $617.3 \pm 1164.6$ & $299.0 \pm 667.7$ & $43.1 \pm 74.8$ & 0.008 \\
\hline FPG (mg/dl) & $95.3 \pm 7.3$ & $95.9 \pm 7.6$ & $92.7 \pm 7.7$ & NS \\
\hline HOMA IR & $2.4 \pm 1.7$ & $3.7 \pm 3.6$ & $2.3 \pm 1.0$ & 0.018 \\
\hline LDL-col (mg/dl) & $108.1 \pm 38.1$ & $117.7 \pm 35.0$ & $103.0 \pm 26.5$ & NS \\
\hline HDL-col (mg/dl) & $50.3 \pm 11.8$ & $49.4 \pm 11.1$ & $46.6 \pm 11.9$ & NS \\
\hline VLDL-col (mg/dl) & $21.6 \pm 10.2$ & $45.5 \pm 60.6$ & $20.4 \pm 10.1$ & 0.002 \\
\hline T-chol (mg/d) & $181.7 \pm 37.4$ & $178.5 \pm 75.9$ & $169.0 \pm 34.8$ & NS \\
\hline TG (mg/dl) & $104.7 \pm 52.7$ & $106.1 \pm 111.1$ & $102.6 \pm 57.5$ & NS \\
\hline $\mathrm{EFT}(\mathrm{mm})$ & $5.49 \pm 0.71$ & $5.05 \pm 0.98$ & $3.62 \pm 0.75$ & $<0.001$ \\
\hline CIMT (mm) & $0.59 \pm 0.12$ & $0.58 \pm 0.12$ & $0.43 \pm 0.8$ & $<0.001$ \\
\hline
\end{tabular}

NS: Not significant; CG: Control group; SH: Subclinic hypothyroidism group; OH: Overt hypothyroidism group; BMI: Body mass index; SBP: Systolic blood pressure; DBP: Diastolic blood pressur.

Table 2. Comparison between whole study groups for EFT and CIMT

\begin{tabular}{lccc} 
& SH & CG & OH \\
& CG & OH & SH \\
\hline EFT & $<\mathbf{0 . 0 0 1}$ & $<\mathbf{0 . 0 0 1}$ & NS \\
CIMT & $<\mathbf{0 . 0 0 1}$ & $<\mathbf{0 . 0 0 1}$ & NS \\
\hline
\end{tabular}

NS: Not significant; CG: Control group; SH: Subclinic hypothyroidism group; OH: Over thypothyroidism group.

the three groups. When the patient groups were evaluated separately, the values of TSH, anti-tpo, anti-tg were detected to be significantly high in $\mathrm{SH}$ group compared with the CG $(p<0.001)$. However, there was no significant difference in terms of age, FT3, FT4 and Homa-IR values between the two groups (Table 1).

TSH and anti-tpo values were significantly high in $\mathrm{OH}$ group compared with the CG $(p<0.001)$. There was a significant difference between the two groups in the values of Homa-IR, anti-tg, VLDL-c, FT3 and FT4. There was no significant difference between the SH group and the CG in the levels of Homa-IR, FT3 and FT4. Compared with the SH group TSH, homa-IR and VLDL-c were significantly high in $\mathrm{OH}$ group; yet, FT3 and FT4 were significantly low. EFT and CIMT values in the $\mathrm{SH}$ were detected to be significantly higher than those in the CG $(p<0.001$, $\mathrm{p}<0.001$ respectively). Similarly, EFT and CIMT values in the $\mathrm{OH}$ group had increased significantly compared with the values in

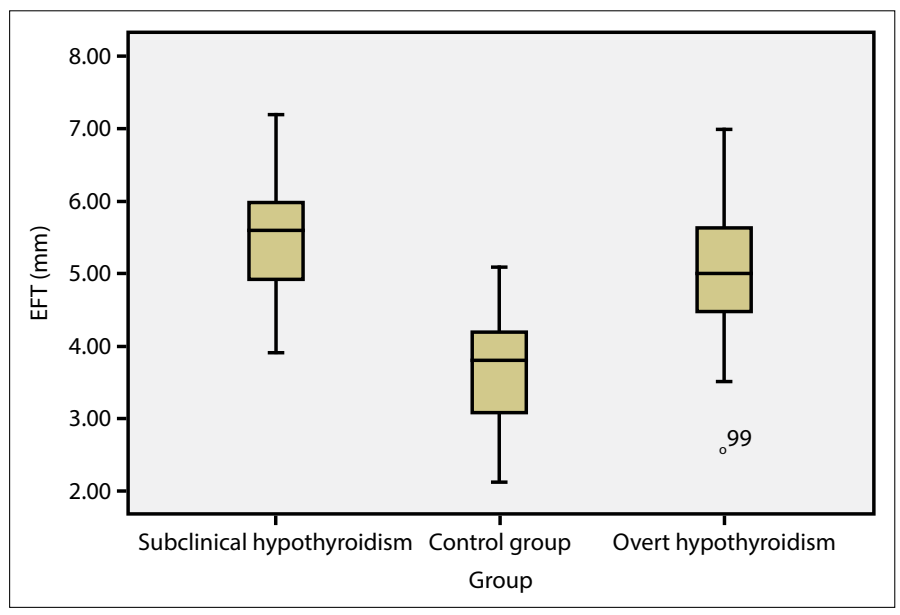

Figure 1. Box plot presentation of epicardial fat thickness in study participants.

the CG $(p<0.001, p<0.001) . \mathrm{OH}$ and SH groups were compared with each other. There was no significant difference between the two groups either in EFT and CIMT values. The relationship concerning EFT and CIMT between the groups are shown in Table 2, Figures 1 and 2.

The regression analysis between EFT and CIMT and all the patients in the study is shown in Table 3 and Table 4 respectively. As seen in the tables, EFT had a significantly positive correlation with age, TSH, anti-tpo, anti-tg and CIMT, yet it had a negative correlation with FT3 and FT4. CIMT had a signifi- 


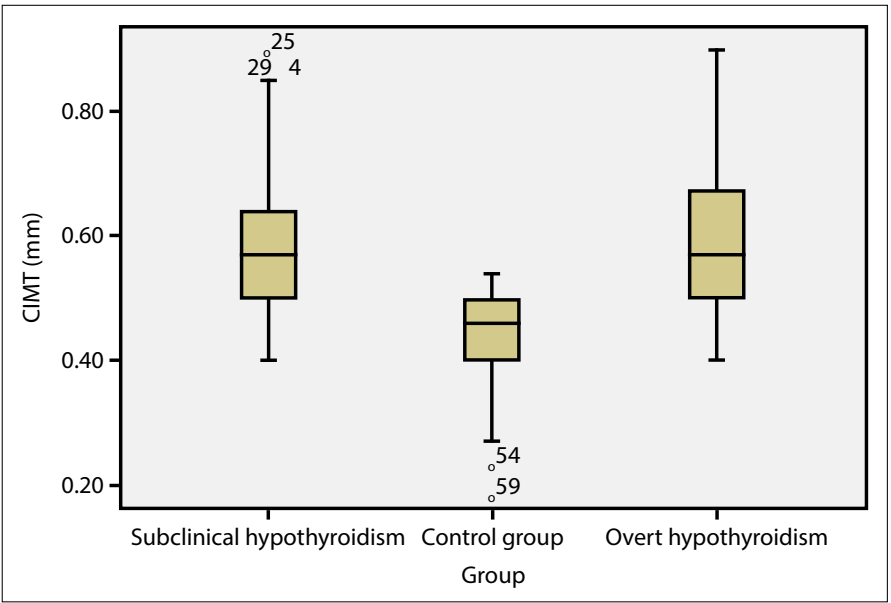

Figure 2. Box plot presentation of carotid intima-media thickness in study participants.

Table 3. Pearson correlation analysis between epicardial fat thickness and other parameters in the whole study group

\begin{tabular}{lcc|ccc} 
& $\mathbf{r}$ & $\mathbf{p}$ & & $\mathbf{r}$ & $\mathbf{p}$ \\
\hline Age & $\mathbf{0 . 2 1 0}$ & $\mathbf{0 . 0 2 2}$ & Anti-TG & 0.317 & $<\mathbf{0 . 0 0 1}$ \\
BMI & 0.130 & NS & HOMA IR & -0.024 & NS \\
SBP & 0.137 & NS & LDL-col & 0.124 & NS \\
DBP & 0.173 & NS & HDL & 0.093 & NS \\
TSH & $\mathbf{0 . 1 9 0}$ & $\mathbf{0 . 0 3 8}$ & VLDL & 0.046 & NS \\
FT3 & $\mathbf{- 0 . 2 4 2}$ & $\mathbf{0 . 0 0 8}$ & T-Col & 0.086 & NS \\
FT4 & $\mathbf{- 0 . 1 9 3}$ & $\mathbf{0 . 0 3 5}$ & TG & 0.026 & NS \\
Anti-TPO & $\mathbf{0 . 4 4 0}$ & $<\mathbf{0 . 0 0 1}$ & CIMT & $\mathbf{0 . 6 9 5}$ & $<\mathbf{0 . 0 0 1}$ \\
\hline
\end{tabular}

BMI: Body mass index; NS: Not significant;.

Table 4. Pearson correlation analysis between carotid intimamedia thickness and other parameters in the whole study group

\begin{tabular}{lcc|lcc} 
& $\mathbf{r}$ & $\mathbf{p}$ & & $\mathbf{r}$ & $\mathbf{p}$ \\
\hline Age & $\mathbf{0 . 2 4 4}$ & $\mathbf{0 . 0 0 8}$ & Anti-TG & $\mathbf{0 . 3 2 0}$ & $<\mathbf{0 . 0 0 1}$ \\
BMI & -0.002 & NS & HOMA IR & 0.013 & NS \\
SBP & 0.132 & NS & LDL-col & 0.137 & NS \\
DBP & 0.159 & NS & HDL & 0.117 & NS \\
TSH & $\mathbf{0 . 2 8 3}$ & $\mathbf{0 . 0 0 2}$ & VLDL & 0.157 & NS \\
FT3 & $\mathbf{- 0 . 2 7 9}$ & $\mathbf{0 . 0 0 2}$ & T-Col & 0.030 & NS \\
FT4 & $\mathbf{- 0 . 1 9 3}$ & $\mathbf{0 . 0 3 6}$ & TG & 0.035 & NS \\
Anti-TPO & $\mathbf{0 . 4 7 4}$ & $<\mathbf{0 . 0 0 1}$ & EFT & $\mathbf{0 . 6 9 5}$ & $<\mathbf{0 . 0 0 1}$ \\
\hline
\end{tabular}

BMI: Body mass index; NS: Not significant;:

cantly positive correlation with age, TSH, anti-tpo, anti-tg, EFT and a negative correlation with FT3 and FT4. There was a positive correlation between EFT and CIMT ( $p<0.001)$. The relationship of TSH, FT3 and FT4 hormone levels with EFT and CIMT was evaluated. According to the Pearson correlation analysis, a positive relationship was seen between the level of TSH and EFT and CIMT. When the level of FT3 was compared with EFT and CIMT, there was a positive correlation between them. When the level of FT4 was compared with EFT and CIMT, a negative correlation similar the one between FT3 and EFT and CIMT was present between them. While the level of FT4 decreased, a significant increase was observed in the levels of EFT and CIMT. When a comparison was made between the values of EFT and CIMT and the levels of anti-tpo and anti-tg in the patients, both EFT and CIMT were positively correlated with both anti-tpo and anti-tg values $(p<0.001)$. When the relationship of EFT and CIMT values with age, BMI, SBP, DBP, FPG, Homa-IR, LDL-c, HDL-c, VLDL-c, T-chol and TG was evaluated, it was seen that there was a significant increase between each of them and age but that there was no significant increase between the other variables and each of them.

\section{Discussion}

Atherosclerosis, commonly seen today, is the most frequent cause of mortality and morbidity. CVD, developing on the basis of atherosclerosis, now comes on top among the causes of death (6). The studies carried out in recent years have highlighted EFT and CIMT too among the risk factors of atherosclerosis. It is recognized that inflammation in the epicardial fat tissue might play a role in coronary atherosclerosis through its effects on vasocrine and paracrine $(7,8)$. It is stated in a number of studies that hypothyroidism induces CAD and that CAD increases in patients with hypothyroid, which is explained to be correlated with an increase in the levels of T-chol, LDL-c, lipoprotein-a and homosistein, which have an aterogenic effect (1). Increased LDL-c, hypercoagulability, obesity, systolic and diastolic hypertension are the mechanisms blamed for the development of atherosclerosis plaque in the patients with hypothyroidism (9). The relationship between $\mathrm{SH}$ and CAD has been the subject of a lot of research, and according to the results of a meta-analysis covering 10 studies, there is at moderate relationship between $\mathrm{SH}$ and increased $\mathrm{CAD}$ and mortality (10). It is also asserted that the major mechanism behind the development of atherosclerosis in $\mathrm{SH}$ is a disorder in the lipid profile and endothelial dysfunction resulting from it (11). Because EFT is not affected by subcutaneous fat tissue, it is accepted as a good marker in determining the risks of both visceral fattening and the resulting CVD (12). Joeng et al. (13) found a positive correlation between severe CAD and EFT in their study. In another study on $\mathrm{SH}$ and $\mathrm{OH}$ patients, Asık et al. (14) identified that EFT increased both in SH and CAD patients. On the other hand, in a recent published study, Korkmaz et al. (15) found that EFT increased not in all SH patients but just in patients with TSH $>10 \mathrm{mIU} / \mathrm{L}$. Santos et al. (16) found that there was not a significant increase in EFT in SH patients with TSH $<10 \mathrm{mlU} / \mathrm{L}$, compared with the control group and maintained that using EFT wouldn't be useful as an early marker for atherosclerosis. However, in our study, EFT increased significantly both in $\mathrm{OH}$ and $\mathrm{SH}$ groups compared with the CG.

We didn't classify SH patients on the basis of TSH $10 \mathrm{mIU} / \mathrm{L}$, but there was a linear correlation between TSH and EFT level. Based on these findings, it could be stated that it may not be 
true to give a threshold value for an increase in EFT in SH and that any increase in the level of TSH may be correlated with an increase in EFT. It is a well-known fact that the expression of TSH receptor increases on the surface of adiposits during the process in which adiposits differentiate and mature (17). Therefore, it may be thought that, in hypothyroid, an increased TSH level could lead to an increase in visceral adipose tissue, and this, in turn, may pose a risk for atherosclerosis and CVD. When $\mathrm{OH}$ and $\mathrm{SH}$ patients were compared with each other in terms of EFT, no significant difference was observed. The rate of increase was similar in both groups. This suggests that both $\mathrm{OH}$ and $\mathrm{SH}$ patients are at nearly the same risk for atherosclerosis. The studies conducted have concluded that CIMT has increased in $\mathrm{OH}$, but the relationship between $\mathrm{SH}$ and CIMT has continued to be a controversial issue. Some studies found that CIMT had increased in SH (18), whereas others failed to find a relationship between the two $(14,15)$. In their study $(18)$, Nagasaki T. et al. detected an increase in CIMT in $\mathrm{OH}$ and SCH patients. On the other hand, Santos et al.(16) detected that CIMT increased in $\mathrm{OH}$ but that it didn't increase in $\mathrm{SH}$. In our study, we found that CIMT increased in the patients with $\mathrm{OH}$ compared with the CG. We also detected CIMT to be high in SH group about which differing views are present, compared with the control group. When we compared $\mathrm{OH}$ and $\mathrm{SH}$ groups with each other, we failed to find a significant difference in terms of CIMT. There are studies stating that a chronic inflammation in hypothyroidism leads to an increase in $\operatorname{CIMT}(19,20)$. Because we detected high antibody titers in the patients in our study, our study supports the view that a chronic inflammation leads to an increase in CIMT. That fact that EFT and CIMT were high in $\mathrm{SH}$ and $\mathrm{OH}$ groups compared with $\mathrm{CG}$ but similar to each other indicates that $\mathrm{SH}$ should also be evaluated, like $\mathrm{OH}$, in terms of the risk for atherosclerosis and CVD. A reason that EFT and CIMT were detected to be high in our patients with hypothyroidism could also be dislipidemia (increased T-chol and LDL-c levels), as our patients both with $\mathrm{SH}$ and $\mathrm{OH}$ had increased LDL-c, TG, T-chol and VLDL-c levels, compared with the CG. Our study also supports the view that EFT and CIMT could be an early marker for coronary atherosclerosis in $\mathrm{SH}$ and $\mathrm{OH}$ patients. Recent studies have maintained that CIMT increases in the patients with hypothyroidism even if thyroid functions are normal and that it could be related to an autoimmune thyroid disease in the background (21). In their study, Asık et al. (14) found that the level of anti-tpo in $\mathrm{SH}$ and $\mathrm{OH}$ groups was significantly higher than in the control group but didn't identify a positive correlation between the level of anti-tpo and EFT. In our study, however, we identified a positive correlation between TSH and the levels of EFT and CIMT. When the patients were grouped as $\mathrm{SH}$ and $\mathrm{OH}$ and their EFT and CIMT were examined, they were found to be higher than in the control group (Figs. 1 and 2).

In both of the groups, anti-tpo and anti-tg levels were significantly higher than in the control group, and a positive correlation was detected between antibody titers and EFT and CIMT, unlike the cases in the aforementioned studies. Because an increase in the on the body titers reflects and inflammatory situation, we are of the opinion that the inflammatory process might have a role in the increase in EFT and CIMT in hypothyroid. Because the severity of hypothyroidism disease is correlated with high TSH level, low FT4 level and high antibody titers, the risk of atherosclerosis and CVD would increase in $\mathrm{SH}$ and $\mathrm{OH}$ with serious or untreated hypothyroid. Markers that foretell this risk may be the increased EFT and CIMT in patients with hypothyroidism as well. When the values of EFT and CIMT were compared with each other, a positive correlation was seen between them. This positive relationship, which is similar to the one we identified, is revealed in a number of studies (14, 22 , and 23). In a sense, EFT turns out to be an indirect marker of CIMT. Because the measurement of EFT is a more challenging process than the measurement of CIMT, it could be considered viable to use CIMT instead of EFT in predicting the risk of atherosclerosis and CVD in patients with hypothyroid.

In conclusion, EFT and CIMT increased both in $\mathrm{OH}$ and SH patients compared with the normal population; therefore, measuring EFT and CIMT may be useful in predicting and preventing the risk of early atherosclerosis. Furthermore, the fact that EFT and CIMT increased in $\mathrm{SH}$ as in $\mathrm{OH}$ requires considering $\mathrm{SH}$, like $\mathrm{OH}$, for the risk of atherosclerosis. Particularly the patients about whom differing views exist as to whether they should be treated or not should be treated so that atherosclerosis risk factors may be reduced, even if they are not symptomatic.

Conflict of interest: There are no relevant conflicts of interest to disclose.

\section{References}

1. Cooper DS, ladenson PW. Greenspans' basic and clinical Endocrinology. 9th Edition chapter 7, 2011;180-97.

2. Cooper DS, Subclinical thyroid disease: A clinician's perspective. Ann Intern Med 1998; 129:135-38.

3. Veltri F, Rocha FO, Willems D et al. Prevalence of thyroid dysfunction and autoimmunity in the older population and implications of age-specific reference ranges. Clinica Chimica Acta 2017;465:34-39.

4. lacobellis G, Willens HJ, Barbaro G, Sharma AM. Threshold values of high risk echocardiographic epicardial fat thickness. Obesity 2008;16(4): 887-92.

5. Kablak-Ziembicka A, Tracz W, Przewlocki T et al. Association of increased carotid intima-media thickness with the extent of coronary artery disease. Heart 2004;90:1286-90.

6. Charles H, Hennekens, MD, Dr PH. Increasing burden of cardiovascular disease. Current knowledge and future firections for research on risc factors. Circulation 1998;97:1095-1102.

7. Mazurek T, Zhang L, Zalewski A, Mannion JD, Diehl JT, Arafat H, et al. Human epicardial adipose tissue is a source of inflammatory mediators. Circulation 2003;108:2460-6.

8. Baker AR, Silva NF, Quinn DW, Harte AL, Pagano D, Bonser RS, et al. Human epicardial adipose tissue expresses a pathogenic profile of adipocytokines in patients with cardiovascular disease. Cardiovasc Diabetol 2006;13:1.

9. Cappola, A.R, Ladenson P.W. Hypothyroidism and athero- 
sclerosis.

J Clin Endocrinol and Metab 2003; 88(6): 2438-44

10. Ochs N, Auer R, Bauer DC, et al. Meta-analysis: subclinical thyroid dysfunction and the risk for coronary heart disease and mortality. Ann Intern Med 2008;148:832-45.

11. Monzani F, Caraccio N, Kozakowa M, et al. Effect of levothyroxine replacement on lipid profile and intima media thickness in hypothyroidism: a double blind, placebo controlled study. J Clin Endocrinol Metab 2004;89(5):2099-106.

12. lacobellis G, Corradi D, Sharma AM. Epicardial adipose tissue: anatomic, biomolecular and clinical relationships with the heart. Nat Clin Pract Cardiovasc Med 2005;2:536-43.

13. Jeong JW, Jeong MH, Yun KH, Oh SK, Park EM, Kim YK, et al. Echocardiographic epicardial fat thickness and coronary artery disease. Circ J 2007;71:536-9.

14. Asik M, Sahin S, Ozkul F, et al. Evaluation of Epicardial Fat Tissue Thickness in Patients with Hashimoto Thyroiditis. Clin En docrinol 2013;79(4):571-6.

15. Korkmaz L, Sahin S, Akyuz AR, Ziyrek M, Anaforoglu I, Kose M, Erkan H, Ağaç MT, Acar Z. Epicardial adipose tissue increased in patients with newly diagnosed subclinical hypothyroidism. Med Princ Pract 2013;22(1):42-6.

16. Santos OC, Silva NA, Vaisman M, Turano MD, Dytz MG, Huber GA, Braulio VB, Teixeira PF. Evaluation of epicardial fat tissue thickness as a marker of cardiovascular risk in patients with subclinical hypothyroidism. J Endocrinol Invest 2015;38(4):421-7.
17. Mamiya S, Hagiwara M, Inoue S, Hidaka H: Thyroid hormones inhibit platelet function and myosin light chain kinase. J Biol Chem 1989;264:8575-79.

18. Nagasaki $T$, Inaba $M$, Henmi $Y$, et al. Decrease in ca $\neg$ rotid intimamedia thickness in hypothyroidism patients after normalization of thyroidfunction. Clin Endocrinol 2003;59:607-12.

19. Taddei S, Caraccio N, Virdis A, Dardano A, Versari D, Ghiadoni L, Ferrannini E, Salvetti A, Monzani F. Low-grade systemic inflammation causes endothelial dysfunction in patients with Hashimoto's thyroiditis. J Clin Endocrinol Metab 2006;91:5076-82.

20. Kvetny J, Heldgaard PE, Bladbjerg EM, Gram J. Subclinical hypothyroidism is associated with a low grade inflammation, increased triglyceride levels and predicts cardiovascular disease in males below 50 years. Clin Endocrinol 2004;61:232-38.

21. Ciccone MM, De Pergola G, Porcelli MT, Scicchitano P, Caldarola P, lacoviello M, et al. Increased carotid IMT in overweight and obese women affected by Hashimoto's thyroiditis: an adiposity and autoimmune linkage? BMC cardiovascular disorders 2010;10(1):22.

22. Cakir, E., Dogan, M., Topaloglu, O., et al. Subclinical atherosclerosis and hyperandrogenemia are independent risk factors for increased epicardial fat thickness in patients with PCOS and idiopathic hirsutism. Atherosclerosis 2013; 226:291-95.

23. Sengul, C., Cevik, C., Ozveren, O., et al. Echocardiographic epicardial fat thickness is associated with carotid intima-media thickness in patients with metabolic syndrome. Echocardiography 2011;28:853-58. 